

\section{VOL. VII.-I893.}

\section{THE JOURNAL}

$\mathrm{OF}$

\section{A R Y N G O L O G Y,}

RHINOLOGY, AND O'TOLOGY;

AV ANAIYTICAL RECORD OF CURKENT LITERATURE KELATING TO

TIE THROAT, NOSE, AND EAR.

EDITED BI

R. NORRIS WOLFENDEN, M.D. Cantab., JOHN MACINTYRE, M.B. Glasgow,

AN(1)

DUNDAS GRANT, M.A., M.D., F.R.C.S. Eng.,

WITH THE ASSISTANCE OF

Dr. BARCLAY J. BARON (Bristol). Dr. SANDFORD (Cork).

And with the co-operation of

DR. RICARDO BOTEY (BARCELONA)

DR. BRYSON DELAVAN (NEW YORK)

Dr. DRAISPUL (ST. PETERSBURG)

PROF. GUYE (AMSTERDAM)

DR. MIDDLEMASS HUNT (LIVERPOOL)

DR. VALERIUS IDELSON (BERNE)

DR. JOAL (PARIS)

DR. KARWOWSKI (WARSAW)

DR. JOHN N. MACKENZIE (BALTIMORE)

DR. GRAZZI (FLORENCE)

DR. SANDFORD (CORK)

DR. LUBET-BARBON (PARIS)
Dr. G. W. MAjor (Montreal)

PROF. MASSEI (NAPLES)

DR. W. ROBERTSON (NEWCASTLE-ON-TYNE)

DR. J. MICHAEL (HAMBURG)

DR. HOLGER MYGIND (COPENHAGEN)

DR. PORTER (ST. LOUIS)

Dr. SAJOUS (PHILAdELPHIA)

DR. SENDZIAK (WARSAW)

Prof. RAMON DE LA SOTA (SEVILLE)

DR. HICGUET (BRUSSELS)

Dr. MILligan (MANChester)

DR. LICHTWITZ (BORDEAUX)

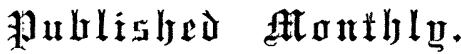

\section{LONDON :}

F. J. REB M A N,
PHILADELPHIA, PA. :

THE F. A. DAVIS COMPANY, I914-I6, Cherry Street.

Albion Chambers, II, Adam Street, Strand.

$$
\text { ENTERED AT STATIONERS' HALL. }
$$




\section{CONTENTS.}

\section{Original Article :-}

On the Therapeutic Value of the Hydro-Carbon in Ceneral, and Hispecially of the "VasogeneKlever." By Dr. BAvEk.

Page 4 60.

Diphtheria and Therapeutics.-Circular on Bacteriulocical Diagnosis of 1)iphtheria, Health Nepretinent ot Vea J ork-Diphtheria and Specific Sore Throat Affertions, fI ill-Causes of Increase of Diphtheria in Urban Districts. Daries-Treatment of Diphtheria, Putnam. Treatment of Iiphtheria by Papavotin and Carbolic Acid, Lezy and Knopf-Ozone in the Treatment of Diphtheria, Haynes - Improved

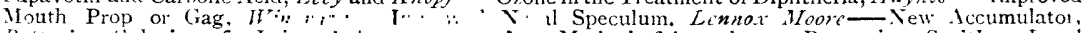

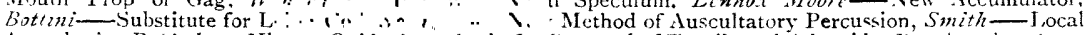
Anesthesia, Dobisch - Nitrous Oxide Anasthesia for Removal of Tonsils and Adenoids, Dututas (irantAntimycotic Properties of Aniline Derivatives, Rohrcr-Treatment of Lupus of Skin, Lramer.

Mouth, Pharynx, \&c Sulunillary Mages 482 to 486 . maxillary Gand, Pas? ling of Sub.

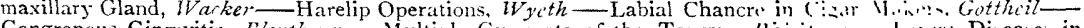

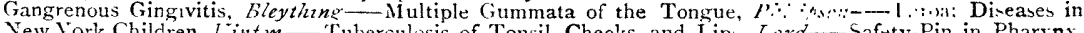
New York Children, I int m_ Tuberculosis of Tonsil. Cheeks, and Lip, Lord_- Safety.Pin in Pharrnx, Huntingdon-1 Esophageal Diverticulum, Dugge-Congenital Occlusion of (T)ophagus. Logan- New Wilator for Stricture of (Fsophagus, Schriti'r.

Nose and Naso.Pharynx. - Nasal Medication with Morphine and Cocaine, Mattison- New Nasal Hougie, Dessar- Nasal Hydrorrhoa, Keiper-Hypertrophic Rhinitis, producing Asthenopia. Fic"nstitu-Treatment of Hay Fever, Ferber-Pathology of Periodical Hyperasthetic Rhinitis (HayFever) and its Treatment by Glacial Acetic Acid, Sajous - Foreign Body in Nose for Twenty-seven Vears. Hanfort-Gelatinous Polypus of Nose, Sheild-Diseases of Pneumatic Sinuses of Nose in Relation to Affections of the Eye, Caidzell___ Empyema of the Maxillary Sinus, Jorea Brocon-Acute Empyema "Intrum, $U$ oifenstcin-Syphilin of Naso-Pharynx, Blair-Hremorrhage from Post-Nasal Growths,

Larynx.-Laryngeal Papilloma, Bark - Intubation in Non-Membranous Stenosis of Larym, Yimpson-Jaryngeal Paralysim, Onodi-- Fatal Spasm of (Hlottis in Hysteria Virilis, Leo Tracheotomy mil Account of Poisuning by Lysol, Raete Surgery of Air-Passays and Thorax in Children, $P$ it s Evitirpation of Larynx. f'oppert-Longitudinal Opening of Trachea for Foreign Body, Stickler.

Pages 498 to ic:

Ear.-Significance of Quantity of Tone in Testing the Hearing, Dennert-Differential Diagnosis of Viddle-lear and I abyrinthine Diseases, f $n n k a u$ - Transparent Preparations of Organ of Hearing, Kat, - - Vew Growths of Ear, Ome Green-External Auditory Canal Injured by Crarotting, Rupp--Hypertrophy "Tympanic IIucou- Membrane in an Infant, Cheatle Rheumatism as a Cause of Partial Deafuess with Tinnitus, tadakin-Function of Fatty Layer in Wall of Eustachian Tube-1utophony, Ustmann-Otitis Nedia Purulenta; Pyomia; Recovery, Bionficla - Pathology of Neaf.Mutism, Lo'e-Temporal Bones of Deaf.Mutes, Holscr .1Yysind-Transillumination of Mastoid Cells, Caldzell-Osteoma of Mastoid, Orme freen Caries of Entire Pyramid of 'lemporal Bone, Thorner-Mastoid Alscess, Sirroedcr-Unintentional Opening of Lateral Sinus Sheppard.

Soclety Reports:-

Wedical and Chirurgical linculty of Mitryland.

Pages 502 to $5 \mathrm{~m}$.

American tiuraical Association.

American Medical Association-Section on Diseases of Children.

Rexievy.-Diseanes of the Larynx, Rosewthal.

Page jic.

Pages 5ri"to 515 .

Page $51:$.

Obltuary,-Julius Heinrich Sommerbrodt.

Notes.- Luryngology in liristul-1ral.

, 516.

New Preparations. - Fffervescent Granules.

Pages 516-517.

Page 517.

\section{GUIDE TO FDYERTISEMENTS.}

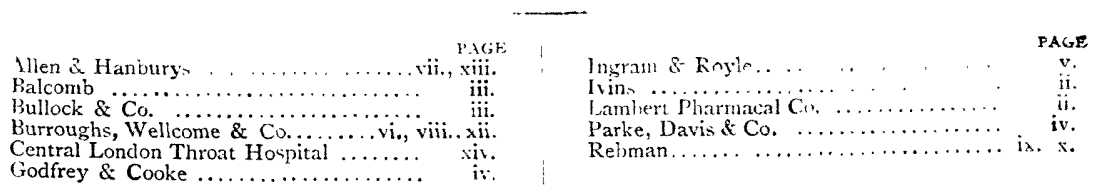


xii.

\section{VOICE AND THROAT.}

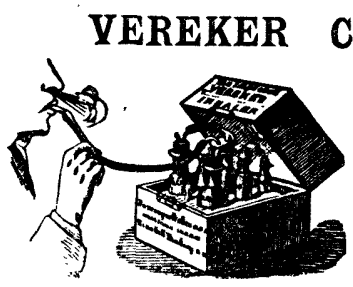

\section{HLORIDE OF AMMONIUM INHALER.}

catarrh has been cured by this vapour. The Vereler Tnhuler is a complete anpatus and incurs no special trouble in using. It is always ready for use.

Supplied to the Medical Profession by all Chemists at 5s. each.

\section{CHLORATE OF POTASH AND BORAX "TABLOIDS."}

The worth of Chlorate of Potash is greatly enhanced by the presence of Borax. Borax is generally known to quickly relieve huarseness, irritation of the throat, and when taken early to avert a cold. It is considered an excellent antiseptic, correcting perverted oral secretions, cleansing the mouth, and imparting to an offensive breath the wholesomeness of perfect health. An excellent way to employ Borax is in the Chlorate of Potash and Burax "Tabloids."

Supplied to the Medical Profession by all Chemists at $4 \mathrm{~d}$. and 6id. per box.

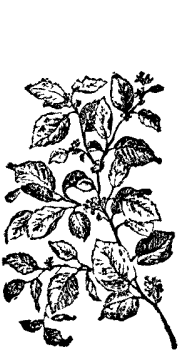

HAZELINE.

One of the very best agents that can be used in catarrh of the nose and throat, by reason of its antiseptic and astringent properties, is Hazeline. Under its use a bad cold abates, and snuffing into the nostrils in catarrh gives comfort. As a gargle in sore throat, quinss, pharyngitis and diphtheritic sore throat, it is very highly praised.

Hazeline supplied to the Medical Profession by all Chemists, in $\frac{1}{4} 1 \mathrm{~b}$. and $1 \mathrm{lb}$. bottles, at $1 \mathrm{~s}$. $2 \mathrm{~d}$. and $3 \mathrm{~s}$. $6 \mathrm{~d}$.

\section{VOICE “TABLOIDS."}

The Voice "Tabloids" contain Cocaine, Chlorate of Potash, and Borax. Cocaine has been largely employed by laryngologists, and is highly valued in many throat affections. It allays irritability of the throat, and tones the mucous membrane of the vocal cords and throat generally. Fuller, clearer, and richer vocal tones follow its use. The best form in which to apply Cocaine for the voice and throat is in the Voice "Tahloids" with Chlorate of Potash and Borax.

Supplied to the Merlical Profession by all Chemists in boxes of 30 and 80 at $8 d$. and $1 \mathrm{~s}$. 4l. each.

BURROUGHS, WELLCOME \& C0., Snow Hill Buildings, London, E.C. 